\title{
Effect of forage species and season on nutrient digestion and supply in grazing cattle
}

\author{
By D. E. BEEVER, H. R. LOSADA, S. B. CAMMELL, R. T. EVANS \\ AND M.J.HAINES \\ Animal and Grassland Research Institute, Hurley, Maidenhead, Berkshire SL6 5LR
}

(Received 27 September 1985 - Accepted 3 February 1986)

\begin{abstract}
1. A total of twenty Friesian steers were grazed on pure swards of either perennial ryegrass (Lolium perenne cv. Melle) or white clover (Trifolium repens cv. Blanca) from May to late August to examine the effect of forage species and season on nutrient digestion and supply. Within each forage species, two daily allowances of forage (i.e. 30 and $60 \mathrm{~g}$ dry matter (DM) $/ \mathrm{kg}$ live weight) were given, and nutrient flow into the small intestine was measured on thirteen separate occasions (viz. seven grasses and six clovers).
\end{abstract}

2. Total nitrogen content of the grasses varied between 28 (early season), 19 (mid-) and 33 (late) g/ $\mathrm{kg} \mathrm{DM}$, whilst the clovers showed a much narrower range and all values were higher $(39-45 \mathrm{~g} / \mathrm{kg} \mathrm{DM})$. In vitro organic matter (OM) digestibilities of plucked samples ranged from 742 to $809 \mathrm{~g} / \mathrm{kg} \mathrm{OM}$ (grass) and 712 to $790 \mathrm{~g} / \mathrm{kg} \mathrm{OM}$ (clover), the lowest values being noted in late June (grass) and mid-July (clover).

3. OM intakes calculated from estimated faecal OM output (using unlabelled ruthenium) and predicted OM digestibility of the consumed forage indicated mean values of 20.9 (grass) and 26.0 (clover) $\mathrm{g} / \mathrm{kg}$ live weight $(P<0.001)$, whilst the higher forage allowances increased OM intake by approximately $8 \%$ on both grass and clover $(P<0.01)$ compared with the low allowance. OM intake was significantly $(P<0.01)$ lower on the two primary growths of grass examined in May (mean $16.8 \mathrm{~g} / \mathrm{kg}$ live weight) than the other five grass diets.

4. Rumen molar propionate levels declined with season but were at all times higher on the grass than on the clover diets, whilst acetate levels were unaffected by forage species. Apart from the late-season grass, mean rumen ammonia concentration was less than $100 \mathrm{mg} \mathrm{NH}_{3}-\mathrm{N} / \mathrm{l}$ on all grass diets, whilst values on the clover diets ranged from $200-350 \mathrm{mg} / \mathrm{l}$.

5. Daily duodenal OM flows in relation to animal live weight were approximately $20 \%$ higher on the clover than on the grass diets (grass 9.2 , clover $11.2 \mathrm{~g} / \mathrm{kg}$ live weight, $P<0.001$ ), but estimates of the proportion of digestible $\mathrm{OM}$ apparently digested in the rumen were not significantly influenced by forage species (grass 0.69 , clover 0.71).

6. Non- $\mathrm{NH}_{3}-\mathrm{N}$ (NAN) flow to the small intestine varied from 0.41 to $0.76 \mathrm{~g} / \mathrm{kg}$ live weight on the grass diets in response to season and forage allowance compared with values of $0.60-0.94 \mathrm{~g} / \mathrm{kg}$ on the clover diets, with the overall forage species effect being statistically $(P<0.001)$ significant (grass 0.60 , clover $0.76 \mathrm{~g} / \mathrm{kg}$ live weight). In relation to estimated $\mathrm{N}$ intakes, however, these findings revealed a considerable loss of $\mathrm{N}$ between mouth and duodenum on the clover diets equivalent to approximately $35 \%$ of $\mathrm{N}$ intake.

7. A significant regression of NAN flow/unit $\mathrm{N}$ intake (NI) $(\mathrm{g} / \mathrm{g})$ on $\mathrm{N}$ content in the forage OM $(\mathrm{g} / \mathrm{kg})$ was obtained for all forages examined:

$$
\mathrm{NAN} / \mathrm{NI}=1.507-0.0185[\mathrm{~N} / \mathrm{OM}] \text {, residual SD } 0.007, r 0.929,
$$

indicating that efficiency of utilization of the $\mathrm{N}$ in fresh forages in the rumen was more closely related to forage $\mathrm{N}$ content than forage species per se.

Forages contribute over 70\% of the metabolizable energy (ME) (Green \& Baker, 1981) and an equally significant proportion of the protein consumed annually by ruminants in the UK, a considerable part of this being consumed in situ by the grazing animal. In contrast, research designed to examine the digestion of, and nutrient supply arising from, forages has concentrated on an examination of conserved materials (Beever, 1980), and to date virtually all the information available on fresh forages has been obtained using stall-fed animals (MacRae \& Ulyatt, 1974; Ulyatt \& MacRae, 1974; Ulyatt \& Egan, 1979; Beever et al. 1971, 1974, 1976, 1978b, 1985; Egan \& Ulyatt, 1980).

The absence of appropriate methodology to estimate nutrient digestion and flow in grazing animals has largely contributed to this situation, but the recent development of 
suitable infusion pumps (Corbett et al. 1976; Evans et al. 1981 a) and an automatic duodenal sampler (Evans et al. 1981 b) has removed this restriction, and studies relating to sheep grazing a variety of forage species in Australia (Corbett et al. 1982) and cattle grazing two temperate species in the UK (Ulyatt et al. 1981) have recently been reported.

The present study comprises the examination of two contrasting forages, i.e. perennial ryegrass (Lolium perenne cv. Melle) and white clover (Trifolium repens $\mathrm{cv}$. Blanca), which were offered at two levels of daily allowance to grazing cattle throughout the major part of the growing season. The experimental measurements commenced in May and were concluded $120 \mathrm{~d}$ later, by which time a total of seven ryegrass and six white clover diets had been examined. The present study was designed as a direct follow-up to the much more limited experimentation reported briefly by Ulyatt et al. (1981). A preliminary report of the present study has been published (Losada et al. 1982).

\section{MATERIALS AND METHODS \\ Forages}

Two pure swards of perennial ryegrass and white clover were used. These swards were the same as the ones used by Beever et al. (1985), but by the time of this experiment they were 4 and 2 years old respectively. Both swards had good ground cover and were virtually weed-free; an early spring application of a selective herbicide to the clover sward prevented any significant ingress of grass to this crop.

\section{Animals}

Twenty Friesian male castrates, approximately 12 weeks old and weighing on average $130 \mathrm{~kg}$ (range $118-137 \mathrm{~kg}$ ) were each fitted with a PVC cannula ( $38 \mathrm{~mm}$ internal diameter (i.d.)) into the dorsal sac of the rumen and a PVC ' $T$ '-piece cannula (13 mm i.d.) into the proximal duodenum (Cammell, 1977), using previously described procedures (Beever et al. 1978a). Afterwards, all animals were individually fed on good-quality hay and lucerne (Medicago sativa) pellets until commencement of the experiment. Immediately before turning out to pasture, the animals (average age 4 months) were weighed (average weight $150 \mathrm{~kg}$, range $137-160 \mathrm{~g}$ ) and randomly allocated according to live weight to one of four groups (i.e. two forages at two dry matter (DM) allowances) for the duration of the whole experiment.

\section{Forage pasture management}

Both forages were topped to $30 \mathrm{~mm}$ in early March and $60 \mathrm{~kg}$ nitrogen/ha as compound fertilizer (N-phosphorus-potassium, 20:10:10) was applied to the grass sward. The clover sward received equal amounts of $P$ and $K$ at the same time, but no $N$ was applied to the clover at any time throughout the whole season. The two swards were then subdivided to provide suitable grazing areas by means of electrified wiring, with each paddock designed to supply adequate grazing for 1 week.

After grazing, each paddock was topped to remove all ungrazed material and cut again (as required) $28 \mathrm{~d}$ before commencement of the next intended grazing. At this time, the grass paddocks (only) received a further $60 \mathrm{~kg} \mathrm{~N} /$ ha as Nitrochalk. Further details with respect to establishment of 4-week-old regrowths were as described by Beever et al. (1985). Before examination of the regrowths (four grass + four clover), a total of three grass and two clover primary growths were examined. The diets, as presented in Table 1 (p. 213), were designated R1-R7 (grass) and W1-W6 (white clover) in the order in which the different crops from each forage species were offered. When the soil moisture deficit exceeded $35 \mathrm{~mm}$, irrigation sufficient to supply $25 \mathrm{~mm}$ water was applied to all swards. 


\section{Management of animals at pasture}

The cattle were turned out to grass in late April and clover in late May. Each group of animals received its daily allowance of forage in two equal amounts at 09.00 and 17.00 hours, by means of electrified fencing which was moved both morning and afternoon, whilst access to the previous day's grazing area (by means of a back fence) was permitted to encourage loafing/lying on the previously grazed area. Daily paddock area allowance was estimated on the basis of dry weight of the standing crop (six quadrats $\left(0.6 \mathrm{~m}^{2}\right)$ taken to ground level twice weekly), the group live weight of the animals (taken weekly) and the DM content of the crop (taken daily). Each forage was offered at two DM allowances, i.e. 30 and $60 \mathrm{~g} / \mathrm{kg}$ live weight.

Animals had access to fresh water and mineral licks at all times, whilst those on clover received an oral dose of poloxalene (Smith, Kline \& French, Welwyn, Herts) twice daily $(10 \mathrm{ml} / \mathrm{d})$ as a bloat preventative.

\section{Experimental procedures}

Within each experimental period, when the calves had been on the appropriate diet (i.e. grass or clover) for a minimum of $10 \mathrm{~d}$, a continuous intraruminal infusion of the non-radioactive forms of ruthenium phenanthroline (RuP; Tan et al. 1971) and CrEDTA was commenced in each animal, using a portable infusion pump (Evans et al. 1981a) in order to permit estimates of duodenal flow and faecal output. On days 6-8 after commencement of marker infusion, faecal samples were manually removed from all animals on three occasions during each day to estimate faecal output (i.e. nine samples/animal per period). At the same time (days 6-8), samples to represent the forage consumed by all groups of animals were taken by hand-plucking and retained for subsequent analysis. On days 7 and 8 of the infusion, samples of duodenal digesta were automatically collected at approximately 10-15 min intervals throughout each day $(24 \mathrm{~h})$, using the portable sampler developed by Evans et al. ( $1981 \mathrm{~b}$ ). Additionally, on day 8, rumen fluid samples $(15 \mathrm{ml})$ were collected from each animal on three separate occasions (10.00, 12.00 and 15.00 hours) to cover the period between the morning and the afternoon allocation of forage.

\section{Sample processing}

Infusates. Following preparation of the markers, appropriate samples were taken to check actual marker concentrations with theoretical values, and any batches of marker which were not adequate in this respect were discarded. Thereafter, infusion solutions, designed to provide $12 \mathrm{mg} \mathrm{Ru}$ and $120 \mathrm{mg} \mathrm{Cr} / \mathrm{d}$ per expected $\mathrm{kg} \mathrm{DM}$ intake, were prepared, and samples of these were retained for subsequent analysis.

Forage. The forage samples which were taken to represent consumed forage (plucked samples) were frozen immediately after collection and subsequently freeze-dried, ground and accumulated before analysis. In addition, the samples taken to estimate dry weight of standing crop were dried at $103^{\circ}$ for $24 \mathrm{~h}$ in a forced-draught oven to estimate forage DM contents.

Faeces. All faecal grab samples were oven-dried at $103^{\circ}$ for $24 \mathrm{~h}$, ground and accumulated on an equal dry-weight basis, for each animal for each day.

Duodenal digesta. Samples of collected digesta were removed from each animal approximately four times during each day, stored at $2^{\circ}$ and finally bulked to provide separate daily samples for each animal. Subsequently, each digesta sample was thoroughly mixed and approximately $500 \mathrm{ml}$ of representative digesta was freeze-dried directly (whole digesta). A further $750 \mathrm{ml}$ was centrifuged at $3000 \mathrm{~g}$ for $10 \mathrm{~min}$ and the residue was retained to provide 
an alternative phase (designated centrifuged digesta) as proposed by Faichney (1975). All samples of whole and centrifuged digesta were then freeze-dried and ground before analysis.

Rumen fluid. All strained rumen fluid samples were immediately acidified after removal with a small volume of concentrated sulphuric acid, and clarified by centrifugation at $3000 \mathrm{~g}$ for $10 \mathrm{~min}$.

\section{Sample analysis}

In vitro organic matter (OM) digestibility of the plucked forage samples was determined according to the technique of Tilley \& Terry (1963), and the values obtained were used to provide estimates of in vivo OM digestibility using the following equation:

$$
y=1.4 x+0.00247(r 0.871)
$$

where $y$ is in vivo OM digestibility $(\mathrm{g} / \mathrm{kg} \mathrm{OM})$ and $x$ is measured in vitro OM digestibility (g/kg OM).

This was obtained in a previous study in this laboratory (M. J. Ulyatt, unpublished observations) using similar animals fed indoors on similar forages to those being examined in the present study.

Additionally, the forage samples were analysed for contents of $\mathrm{OM}$ (by ashing at $550^{\circ}$ overnight), total $\mathrm{N}$ (microKjeldahl, with an automated alkaline phenate hypochlorite colorimetric procedure), water-soluble carbohydrate (acid hydrolysis of cold-water extract (Bailey, 1964) and reaction with alkaline ferricyanide), cellulose (Crampton \& Maynard, 1938) and lignin (Van Soest \& Wine, 1967).

All duodenal digesta samples were analysed for total $\mathrm{OM}, \mathrm{N}$, ammonia and cellulose contents, according to the technique used by Beever et al. (1985). Cr content was estimated following acid digestion using the procedures of Christian \& Coup (1954) and atomic absorption spectrophotometry. Ru contents of infusates, digesta and faecal samples were estimated by X-ray fluorescence spectrometry, as described by Evans et al. (1977). OM content of faeces was determined by overnight ashing, as described previously.

Rumen fluid samples were analysed for $\mathrm{NH}_{3}$ concentration according to the technique used by Beever et al. (1985), and concentrations of volatile fatty acids (VFA) by means of gas-solid chromatography (Hewlett Packard 5700A) with chromosorb 101 (mesh 80-100) as the support phase operating at $160^{\circ}$ with an $\mathrm{N}_{2}$ gas flow of $60 \mathrm{ml} / \mathrm{min}$.

\section{Calculations}

Corrected daily flows of nutrients to the small intestine were estimated using the dual-phase marker technique outlined by Faichney (1975) from the concentrations of $\mathrm{Ru}, \mathrm{Cr}$ and specific nutrients in the whole and centrifuged digesta, in relation to the mean quantities of $\mathrm{Ru}$ and $\mathrm{Cr}$ infused during the day of the collection and the preceding day. Faecal output of $\mathrm{OM}$ was estimated from the $3 \mathrm{~d}$ mean concentration of $\mathrm{Ru}$ in the faecal $\mathrm{OM}(\mathrm{mg} / \mathrm{g})$ and the mean quantity of $\mathrm{Ru}(\mathrm{mg} / \mathrm{d})$ dosed over the $2 \mathrm{~d}$ preceding and each day of the faecal sampling. Finally, OM intake was derived from the estimated output of indigestible OM and $\mathrm{OM}$ digestibility of the plucked forage.

From the overall number of observations on intake and nutrient flow planned ( $n$ 130), values relating to two animals fed on grass and five animals (four on two occasions) fed on clover were not obtained for reasons relating to equipment and harness failure, etc. Consequently these values $(n 11)$ were estimated by the missing-plot technique. Additionally, no values for diet $\mathrm{R} 3$ (see Table 1) relating to rumen VFA and $\mathrm{NH}_{3}$ concentrations were obtained, and the values presented relate to twelve forage comparisons only. 


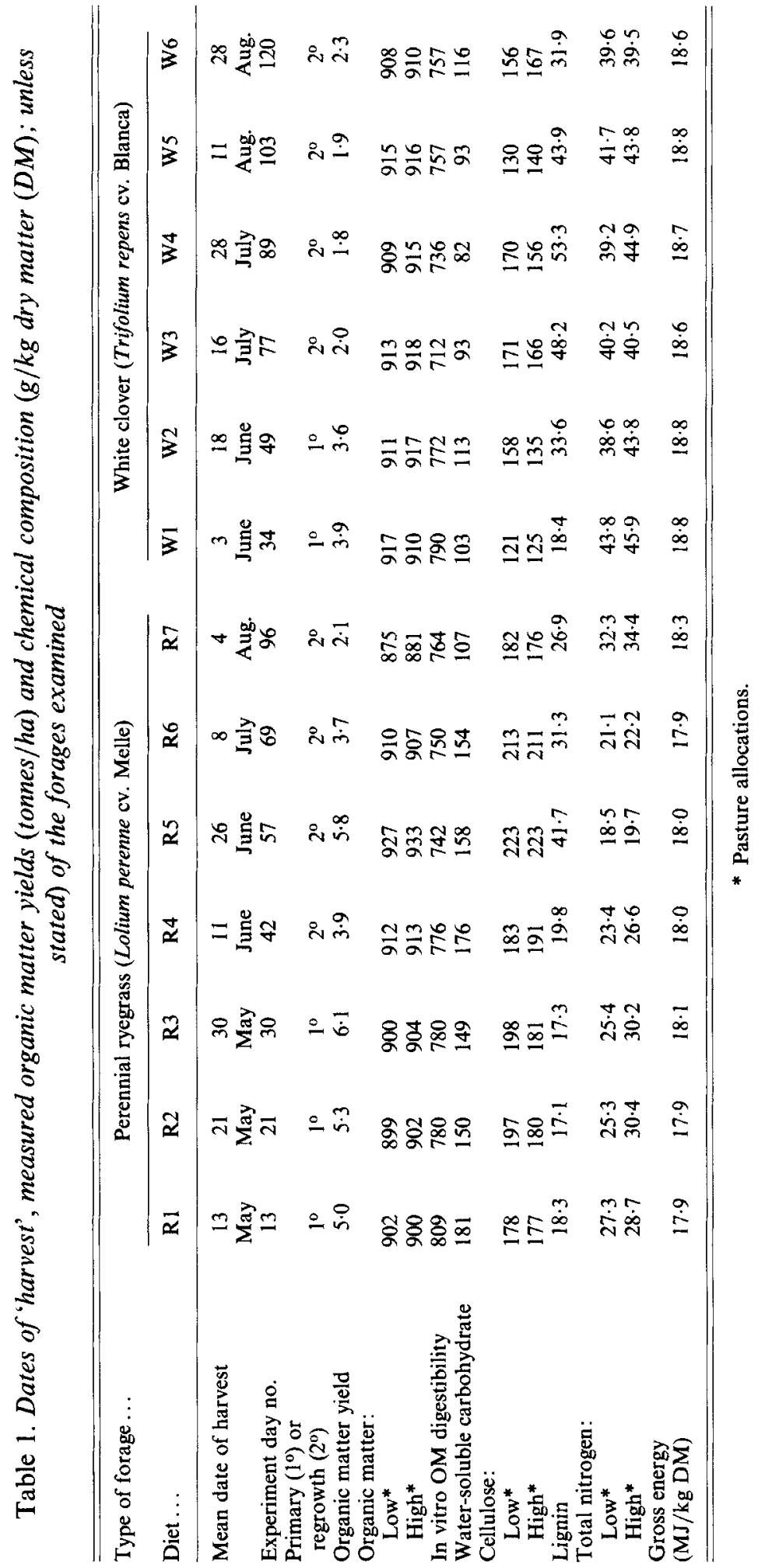


Table 2. Mean live weight $(\mathrm{kg})$ of the animals during each experimental period

\begin{tabular}{|c|c|c|c|c|c|c|}
\hline \multirow[b]{2}{*}{ Diet } & \multirow{2}{*}{$\begin{array}{l}\text { Type of forage ... } \\
\text { Forage allowance. }\end{array}$} & \multicolumn{2}{|c|}{$\begin{array}{c}\text { Perennial ryegrass } \\
\text { (Lolium perenne cv. Melle) }\end{array}$} & \multirow[b]{2}{*}{ Diet } & \multicolumn{2}{|c|}{$\begin{array}{c}\text { White clover } \\
\text { (Trifolium repens cv. Blanca) }\end{array}$} \\
\hline & & High & Low & & High & Low \\
\hline R1 & & 148 & 150 & W1 & 165 & 165 \\
\hline $\mathrm{R} 2$ & & 146 & 149 & $\mathbf{w} 2$ & 179 & 176 \\
\hline R3 & & 160 & 158 & W3 & 213 & 189 \\
\hline R4 & & 167 & 164 & W4 & 212 & 197 \\
\hline R5 & & 185 & 179 & W5 & 239 & 220 \\
\hline R6 & & 188 & 181 & W6 & 252 & 226 \\
\hline R7 & & 214 & 199 & & & \\
\hline
\end{tabular}

\section{Statistical assessments}

The diets were confounded with periods within which the feeding-level comparison for each forage was made. Averaged over the season, the data were analysed as a $2 \times 2$ factorial design to assess forage and feeding-level effects and their interactions. Effects of stage of growth within each forage and averaged over feeding levels, i.e. period means for each forage, were compared using $t$ test.

\section{RESULTS}

A total of seven perennial ryegrass and six white clover diets were studied, details of which are included in Table 1. The pattern of grass growth, as illustrated by measurements of the weight of standing crop, showed peaks of production in May and in late June, with reduced yield in early June and a significant decline by early August. With the possible exception of the late summer period, the yields of clover were at all times less than those reported for the grass, but the pattern of production tended to be more even. With respect to chemical composition, notable differences were observed in total $\mathrm{N}$ content, which varied for the grass diets from 28 (early season) to 19 (mid-season) and 33 (late season) $\mathrm{g} / \mathrm{kg} \mathrm{DM}$. This was at all times lower than the clover diets, which showed a much narrower range (39-45 g/kg DM). Mean in vitro OM digestibility on the grasses showed a steady decline between R1 and R5 from 0.81 to 0.74 , whilst slightly higher values $(0.75$ and 0.76$)$ were noted on the late-season grasses. W1 and W2 had similar in vitro OM digestibilities to the early-season grasses, but particularly low values were noted on W3 and W4 (mean 0.72), whilst slight increases were noted with diets W5 and W6 (0.76). The grass diets had higher contents of water-soluble carbohydrate and cellulose, but lignin contents, whilst low on all diets, tended to be highest on the clover diets. Gross energy content was higher on the clover $(18.7 \mathrm{MJ} / \mathrm{kg} \mathrm{DM})$ than on the grass $(18.0 \mathrm{MJ} / \mathrm{kg} \mathrm{DM})$ diets.

\section{Live-weight changes}

Values relating to changes in animal live weight are given in Table 2. Over the whole experiment animal live weight increased from 149 to $207 \mathrm{~kg}$ (grass) and from 150 to $239 \mathrm{~kg}$ (clover), indicating average live-weight gains of 0.70 and $0.86 \mathrm{~kg} / \mathrm{d}$ for grass and clover respectively.

\section{OM consumption}

OM intakes, estimated according to the technique previously described, are presented, in relation to mean live weights, in Table 3.

Overall, OM intakes on the grass diets averaged $20.9 \mathrm{~g} / \mathrm{kg}$ live weight, which was 


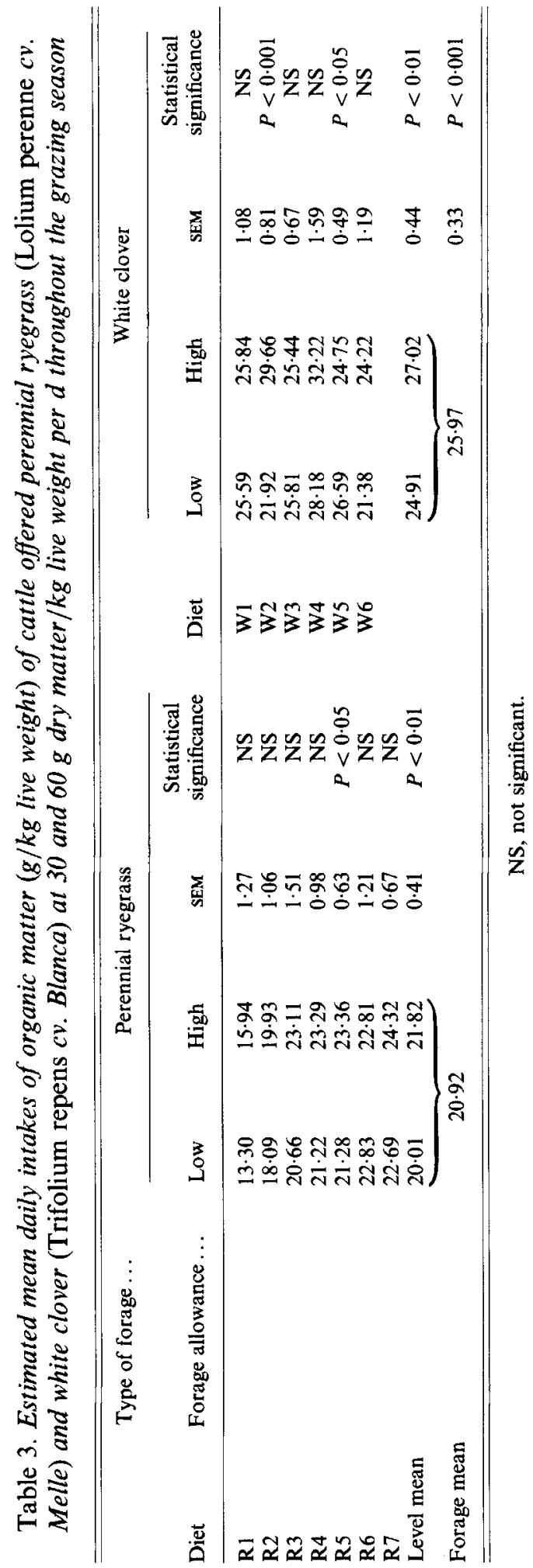




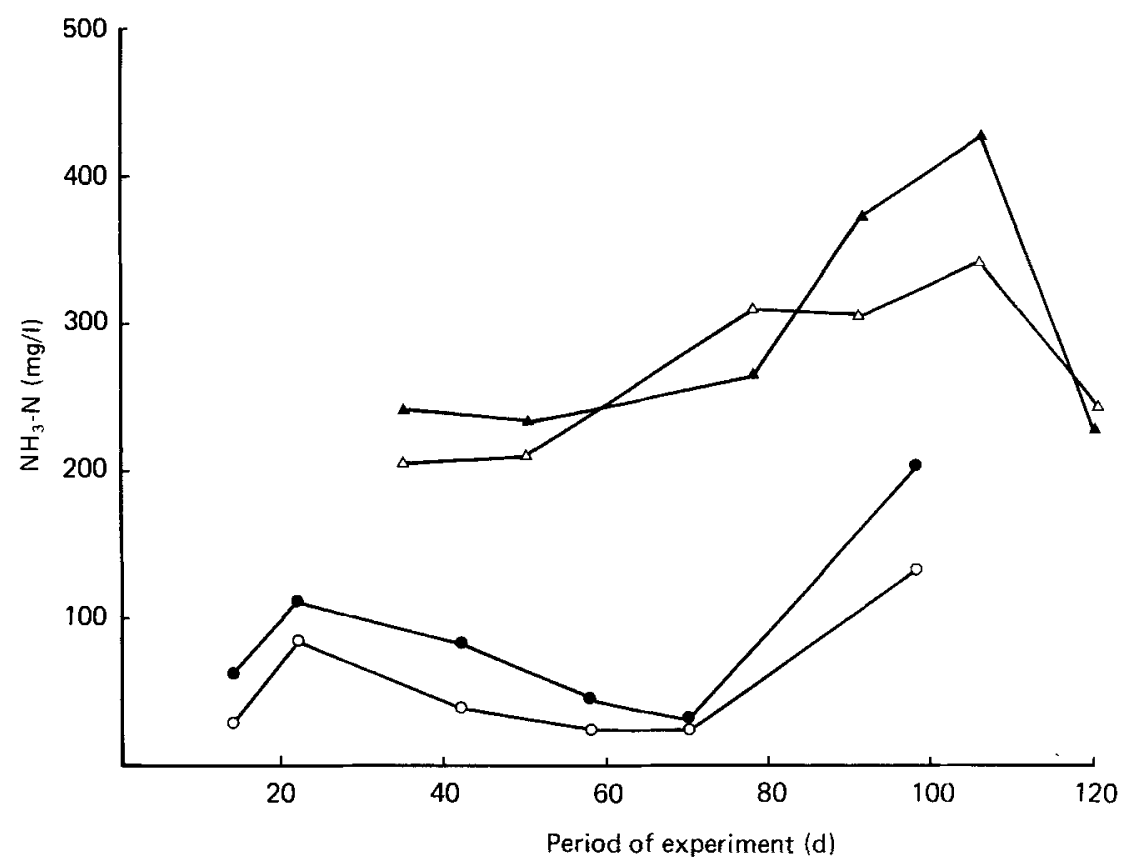

Fig. 1. Mean daily concentrations of rumen ammonia-nitrogen $(\mathrm{mg} / \mathrm{l})$ in cattle offered perennial ryegrass (Lolium perenne cv. Melle) $(O, O)$ or white clover (Trifolium repens $\mathrm{cv}$. Blanca) $(\Delta, \mathbf{\Delta})$ at $30(\mathrm{O}, \triangle)$ and $60(\mathbf{O}, \mathbf{A}) \mathrm{g}$ dry matter $/ \mathrm{kg}$ live weight per $\mathrm{d}$ throughout the grazing season.

significantly $(P<0.001)$ lower than the mean value of $26.0 \mathrm{~g} / \mathrm{kg}$ estimated for animals consuming the clover diets. The overall effect of doubling forage allowance was to increase OM consumption by approximately $8 \%$ on both the grass $(P<0.01)$ and the clover $(P<0.01)$ diets. With respect to season, significant differences in response to increased allowance were only observed on the grass in late June (R5) $(P<0.05)$ and the clover diets in mid-June (W2) $(P<0.001)$ and early August (W5), although the significance of these differences when compared with the responses noted on the other diets is biologically meaningless. OM intake was significantly $(P<0.05)$ lower on $\mathrm{R} 1$ compared with $\mathrm{R} 2$, and significantly $(P<0.01)$ lower for both $\mathrm{R} 1$ and $\mathrm{R} 2$ compared with the other five grass diets. On the clover diets, OM intake was significantly $(P<0.01)$ higher on $\mathrm{W} 4$ and significantly $(P<0.05)$ lower on W6 compared with all other diets.

\section{Rumen fermentation indices}

The mean rumen $\mathrm{NH}_{3}$ concentrations for all forages are illustrated in Fig. 1. Effects due to forage species and season were most pronounced, whilst those attributable to level of forage allowance appeared minimal. On the grass diets, early season values were less than $100 \mathrm{mg} \mathrm{NH} \mathrm{N}_{3} \mathrm{~N} / \mathrm{l}$, declining to $20-40 \mathrm{mg} / \mathrm{l}$ by mid- to late June, values which coincided with the low content of $\mathrm{N}$ seen in this diet (R5). Thereafter, values increased to give $\mathrm{NH}_{3}$, concentrations of $130-200 \mathrm{mg} \mathrm{N} / 1$ for diet R7. In contrast, the clover diets gave higher values, ranging from $200-240 \mathrm{mg} / \mathrm{l}$ in early and late season to values in excess of $350 \mathrm{mg} / \mathrm{l}$ in early August.

Total VFA concentrations averaged $93 \mathrm{mmol}$ (range 73-110) on the grass diets compared with $116 \mathrm{mmol}$ (range 104-134) on the clover diets $(P<0.001)$ (overall SEM 2.60 ), with small but inconsistent effects due to season and level of forage allowance. Molar proportions of 


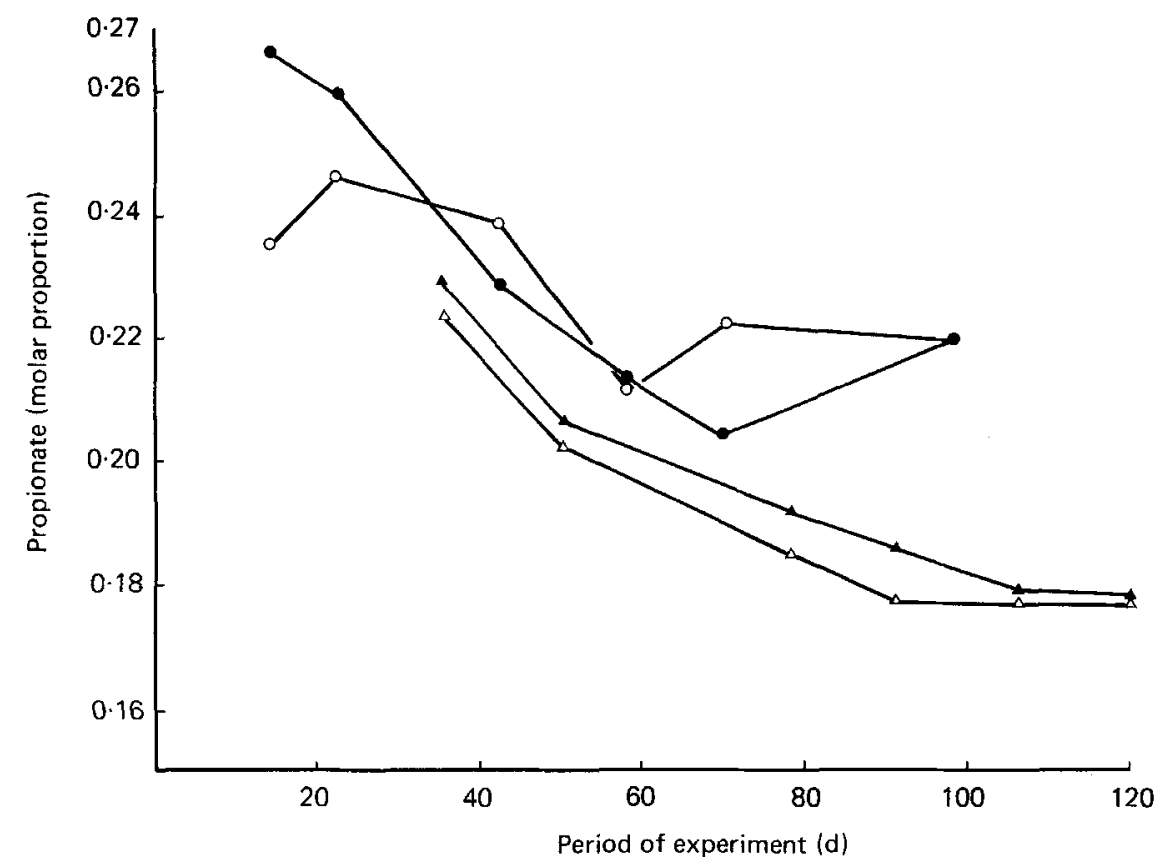

Fig. 2. Mean molar proportions of propionic acid in the rumen fluid of cattle offered perennial ryegrass (Lolium perenne $\mathrm{cv}$. Melle) $(\mathrm{O}, \boldsymbol{O})$ or white clover (Trifolium repens $\mathrm{cv}$. Blanca) $(\Delta, \boldsymbol{\Delta})$ at $30(\mathrm{O}, \Delta)$ and $60(0, \Delta) \mathrm{g}$ dry matter $/ \mathrm{kg}$ live weight per $\mathrm{d}$ throughout the grazing season.

acetate were not significantly affected by season, forage allowance or forage species, with mean values of 0.66 on both forages. In contrast, molar proportions of propionate (Fig. 2) appeared to be influenced by both forage species, with lower values being recorded on the clover diets, and by season, with both diets showing a general decline throughout the study. In contrast, rumen molar proportions of butyrate tended to increase with advancing season and were highest at all times on the clover diets $(0 \cdot 13-0 \cdot 15)$ compared with the grass diets $(0 \cdot 09-0 \cdot 12)$. However, the values obtained on the clover diets were known to include small quantities of isobutyrate.

\section{Nutrient digestion and supply}

The reliability of duodenal digesta flow estimates has been widely debated, and it is not the intention in this paper to elaborate further on the suitability of the various approaches which have been adopted. It is generally accepted that the dual-phase marker method as proposed by Faichney (1975) gives reliable estimates of digesta flow in stall-fed animals, but the applicability of this technique to grazing animals has not been established. It is accepted that absolute verification of digesta flow estimates is not possible, and within the context of the present study it is only possible to indicate the magnitude and the variability of the derived reconstitution factors ( $R$ values). For all diets, a mean $R$ value of -0.05 (SEM 0.013) was obtained, with values for grass being lower $(-0.03$ (SEM 0.016)) than that for clover ( -0.07 (SEM 0.021$)$ ), whilst 0.74 of all values were within the range of -0.24 to $+0 \cdot 24$. These values in themselves give no overall indication of the accuracy of the flow estimates but indicate that the degree of unrepresentative sampling (representative when $\mathrm{R}=0$ ) was not excessive.

$O M$. Total $\mathrm{OM}$ flow to the small intestine increased throughout the season, chiefly in 


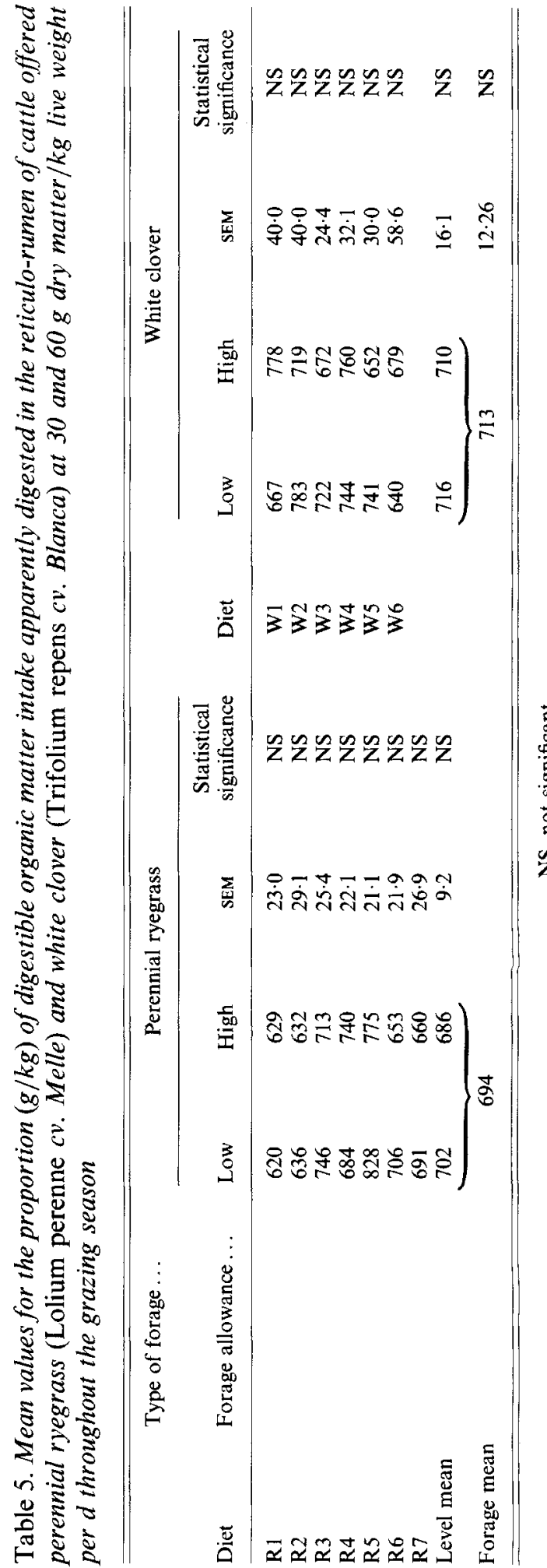


Effect of forage species on nutrient digestion
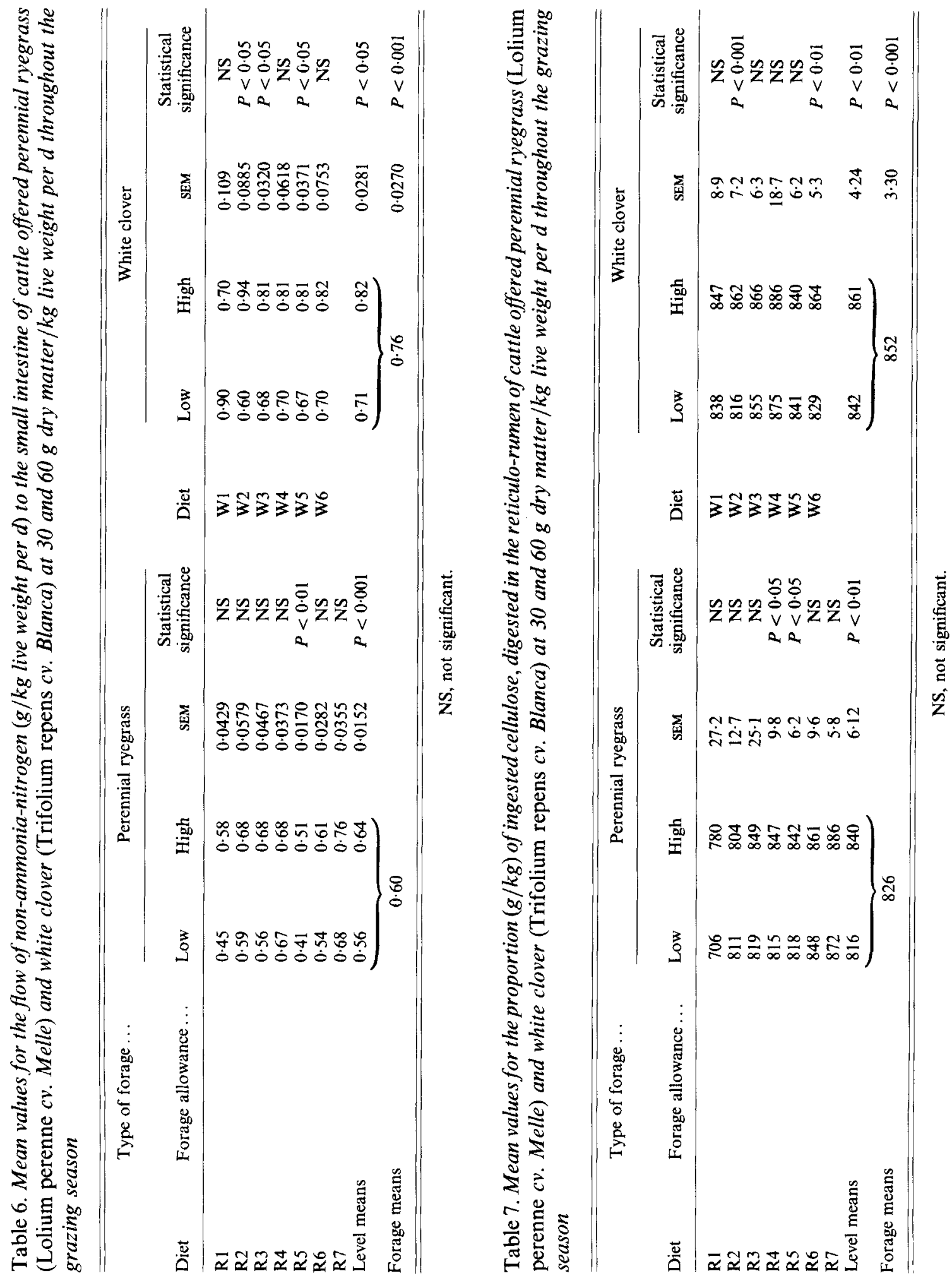
response to the increased quantities of OM consumed by the animals. Higher flows were observed on the clover compared with the grass diets, whilst effects with each forage due to both daily forage allowance and season were detected. These findings are summarized in Table 4, where OM flow $(\mathrm{g} / \mathrm{d})$ has been expressed per $\mathrm{kg}$ animal live weight. Between the grass and the clover diets a significant $(P<0.001)$ difference was observed $(\mathrm{g} / \mathrm{kg}$ live weight: grass 9.2 , clover 11.2 ), whilst significant increases of $10 \%$ in $\mathrm{OM}$ flow were noted on the high compared with the low allowances for both forages (grass $P<0.001$; clover $P<0.05$ ). For diets R2-R5, overall forage mean values varied little from $9.0 \mathrm{~g} / \mathrm{kg}$ live weight, whereas $\mathrm{R} 1$ gave significantly $(P<0.01)$ lower $(7.0)$ and diets R6 and R7 significantly $(P<0.01)$ higher mean values $(10.5$ and $10.8 \mathrm{~g} / \mathrm{kg}$ live weight respectively). Significant differences within individual forages, due to level of allowance, were only detected on diets R5 and R6 $(P<0.01$ and $P<0.05$ respectively). On the clover diets OM flow was significantly $(P<0.05)$ lower on W2 compared with W4, whilst significant differences due to forage allowance were noted on diet W2 $(P<0.05)$. From these values, the estimates of faecal OM production and the derived measures of OM intake, estimates of digestible OM intake (DOMI), were used to calculate the extent of rumen OM digestion (see Table 5).

Overall values for grass and clover were not significantly different $(0.69$ and 0.71 respectively) and no significant overall or individual differences with respect to level of forage allowance were established. Within the seven grasses examined, $R 1$ and $R 2$ were significantly $(P<0.01)$ lower than R3 and R4, whilst R5 was significantly $(P<0.001)$ higher than all other diets. On the clover diets, mean values ranged between 0.70 and 0.75 for all except diet W6 $(0.66)$, which was significantly $(P<0.05)$ lower than diets W2 and W4.

Non- $N_{3}-N(N A N)$. The measured flows of NAN to the small intestine are presented in Table 6, appropriately scaled to animal live weight. A significant $(P<0.001)$ overall difference of $0.16 \mathrm{~g} / \mathrm{kg}$ live weight per $\mathrm{d}(29 \%)$ in favour of the clover diets was observed (grass 0.60 , clover 0.76 ), whilst responses of approximately $0.10 \mathrm{~g} / \mathrm{kg}$ live weight per $\mathrm{d}$ were noted on the high $v$. low forage allowances of grass $(P<0.001)$ and clover $(P<0.05)$. Within forages, effect of season was most pronounced on the grass-fed animals. Significantly $(P<0.05)$ lower values were obtained on diet $\mathrm{R} 5$, compared with diets $\mathrm{R} 2, \mathrm{R} 3, \mathrm{R} 4, \mathrm{R} 6$ and $\mathrm{R} 7$, whilst $\mathrm{R} 1$ also gave values significantly $(P<0.05)$ lower than those noted on diets R2, R3, R4 and R7. Equally, values on diet R6 were significantly $(P<0.05)$ lower than those seen on diets R4 and R7, which did not differ from each other. On the clover diets, despite some variation with respect to season and level of feeding (range $0.60-0.94 \mathrm{~g} / \mathrm{kg}$ live weight per d), no statistically significant seasonal variation was found, but within forage allowance, significantly higher flows were observed on diets W2, W3 and W5 $(P<0.05)$.

Cellulose. Values relating to the proportion of ingested cellulose digested in the rumen are presented in Table 7 . With the exception of values for diet $\mathrm{R} 1$, all values exceeded $800 \mathrm{~g} / \mathrm{kg}$ consumed, with overall forage means of 852 and $826 \mathrm{~g} / \mathrm{kg}$ (clover $>$ grass, $P<0.001)$. Equally, significant $(P<0.01)$ differences with respect to forage allowance were detected on both forages, and also within specific forages (R4 and R5, $P<0.05$; W2 and W6, $P<0.001)$. Consistent seasonal effects were not evident, apart from the significantly $(P<0.01)$ lower values noted on diet $\mathrm{R} 1$ compared with all other grass diets.

\section{DISCUSSION}

The objective of this experiment was to extend the limited number of observations reported by Ulyatt $e t$ al. (1981) on the effect of forage species on nutrient digestion and supply in grazing cattle. The experiment examined both perennial ryegrass and white clover over $120 \mathrm{~d}$ of the growing season from early May to late August, during which time seven grass and six legume diets were studied, with each forage being offered at two DM allowances. 


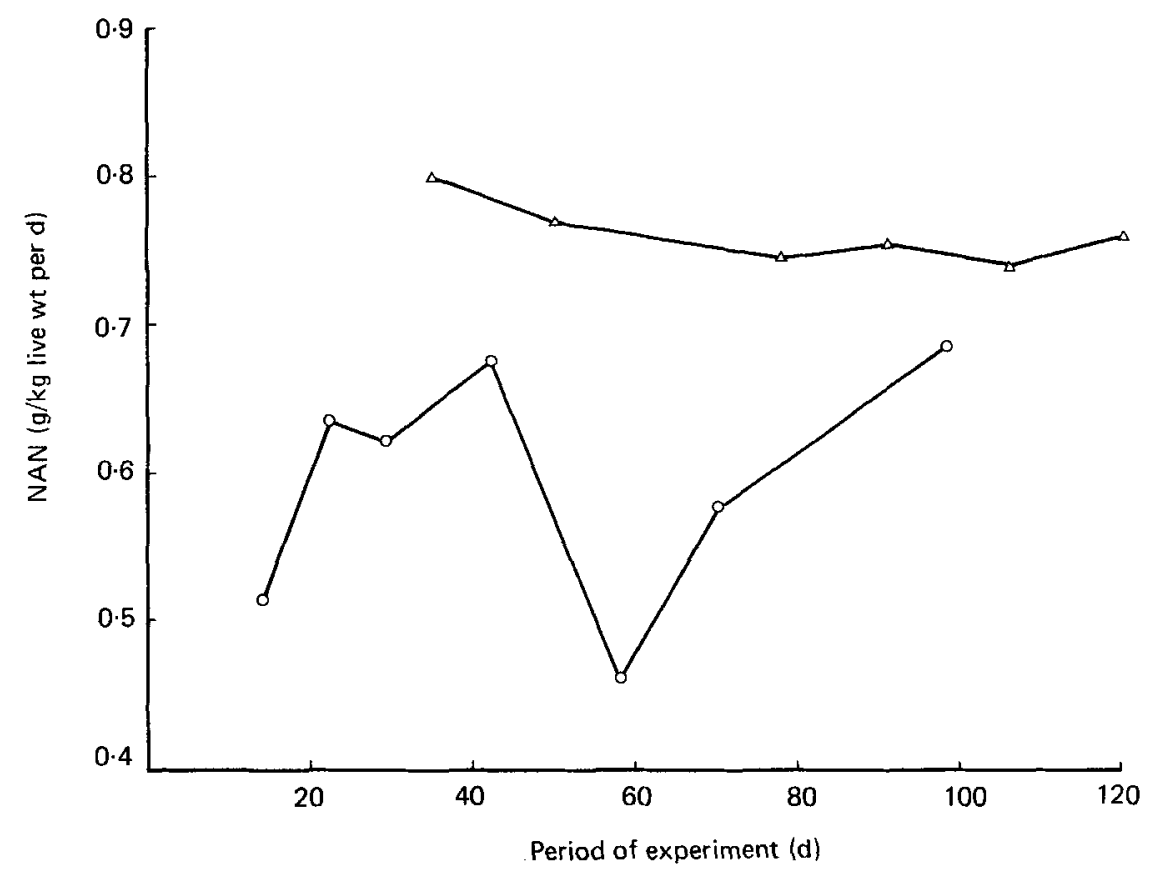

Fig. 3. Mean flows of non-ammonia-nitrogen (NAN; $/ \mathrm{kg}$ live weight per d) into the duodenum of cattle offered perennial ryegrass (Lolium perenne cv. Melle) $(O)$ or white clover (Trifolium repens cv. Blanca) $(\triangle)$ at 30 and $60 \mathrm{~g}$ dry matter $/ \mathrm{kg}$ live weight per $\mathrm{d}$ throughout the grazing season.

The most marked effect noted was the influence of forage species on NAN flow to the small intestine. On the white-clover diets, an overall improvement of almost $30 \%$ compared with the grass diets was observed, whilst significant seasonal effects were detected, notably on the grass diets. The values obtained for each forage type have been combined with respect to forage allowance and the overall effects are illustrated in Fig. 3. On the grass diets, duodenal NAN flow $/ \mathrm{kg}$ live weight was low, both in early season in response to the lower levels of OM consumption and in mid-season, when forage $N$ content declined below $20 \mathrm{~g} / \mathrm{kg}$ DM. In contrast, the clover diets gave consistently higher and less variable quantities of duodenal NAN flow to the small intestine throughout the whole season.

Initially it would appear that this effect of forage species is due to both the higher contents of $\mathrm{N}$ noted on the clover diets (on average $60 \%$ greater than that for grasses) and the greater consumption of $\mathrm{OM}(+0.5 \mathrm{~kg} / \mathrm{d})$ seen on these diets. Consequently total $\mathrm{N}$ intake on the clover diets was almost twice that estimated for the grass diets $(1.18 v 0.62 \mathrm{~g} / \mathrm{kg}$ live weight per d). In contrast, this difference only amounted to an extra $0 \cdot 16 \mathrm{~g} \mathrm{NAN} / \mathrm{kg}$ live weight per $d$ flowing to the small intestine of the clover-fed cattle (clover 0.76 , grass $0.60 \mathrm{~g} / \mathrm{kg}$ per $\mathrm{d}$ ), with the mean value for the clover diets being considerably less than mean $\mathrm{N}$ intake. This phenomenon is illustrated in Fig. 4 , where both mean rumen $\mathrm{NH}_{3}$ concentrations and NAN flow per unit $N$ consumed have been related to the $\mathrm{g} \mathrm{N} / \mathrm{kg}$ OM content in the diet considered to be selected by the grazing animal. For the grass diets R1-R6 (excluding R3) (21-31 g N/kg OM), NAN flow/N intake ranged from 0.88 to $1.17 \mathrm{~g} / \mathrm{g}$ (mean 1.02 ) and rumen $\mathrm{NH}_{3}$ concentrations were all less than $100 \mathrm{mg} \mathrm{NH}_{3} \mathrm{~N} / \mathrm{l}$ (values for $\mathrm{R} 3$ not included). Diet R7 had a higher $\mathrm{g} \mathrm{N} / \mathrm{kg} \mathrm{OM}$ (38) compared with all other grass diets, and this was associated with a depressed NAN flow $/ \mathrm{N}$ intake $(0.77 \mathrm{~g} / \mathrm{g})$ and an elevated mean rumen $\mathrm{NH}_{3}$ concentration $(170 \mathrm{mg} / \mathrm{l})$. The six clover diets had dietary N/OM contents ranging from 43 to $49 \mathrm{~g} / \mathrm{kg}$, and NAN flows $/ \mathrm{N}$ intake varied between 0.54 and $0.75 \mathrm{~g} / \mathrm{g}$, indicating 


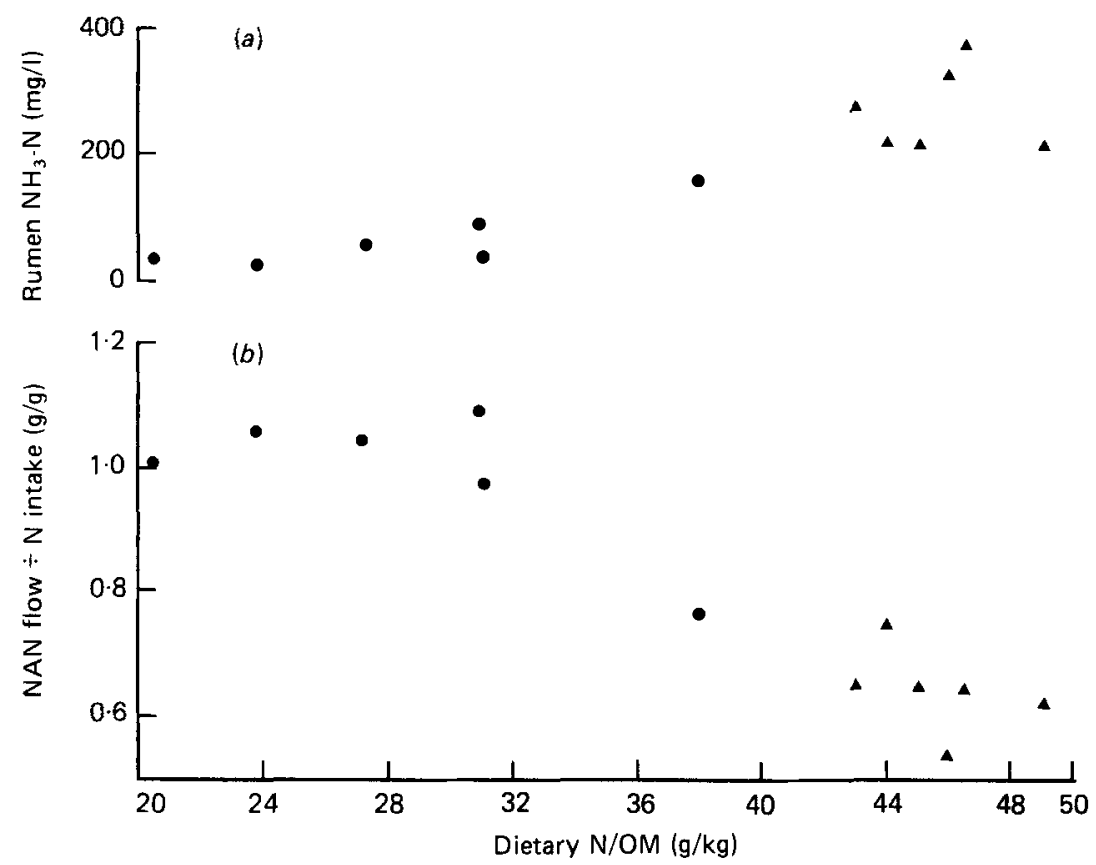

Fig. 4. Relations between the content of nitrogen in the forage organic matter $(\mathrm{OM} ; \mathrm{g} / \mathrm{kg})$ and $(a)$ the concentration of rumen ammonia- $\mathrm{N}(\mathrm{mg} / \mathrm{l})$ and $(b)$ the flow of non- $\mathrm{NH}_{3}-\mathrm{N}$ (NAN) to the duodenum per unit intake $(\mathrm{g} / \mathrm{g}$ ) in cattle offered perennial ryegrass (Lolium perenne cv. Melle) (O) or white clover (Trifolium repens cv. Blanca) (A) at 30 and $60 \mathrm{~g}$ dry matter $/ \mathrm{kg}$ live weight per $\mathrm{d}$ throughout the grazing season.

substantial losses of dietary $\mathrm{N}$ before the small intestine. These losses, in turn, were associated with elevated rumen $\mathrm{NH}_{3}$ concentrations $(230-390 \mathrm{mg} / 1)$.

The overall relation between NAN flow $/ \mathrm{N}$ intake $(y, \mathrm{~g} / \mathrm{g})$ and dietary $\mathrm{N}$ in the $\mathrm{OM}$ $(x, \mathrm{~g} / \mathrm{kg})$ was best described by the linear regression:

$$
y=-0 \cdot 01854 x+1 \cdot 5074 \text { (residual SD (RSD) } 0 \cdot 00743, r 0 \cdot 929 \text { ), }
$$

which accounted for $86 \%$ of the variation.

From a theoretical consideration, the data should be best described by an exponential function, but within the data set available it was not possible to achieve this. However, the overall relation as presented suggests that the major cause of the differences in NAN flow/N intake was more closely related to the content of $\mathrm{N}$ in the forages than to forage species per se, for which separate relations could not be established. One feature which can be developed from the relation is that NAN flows equal to or exceeding $\mathrm{N}$ intake would only be expected when $\mathrm{g} \mathrm{N} / \mathrm{kg} \mathrm{OM}$ content in the forage was less than 27.4 (approximately $24.5 \mathrm{~g} / \mathrm{kg} \mathrm{DM}$ ). This agrees with the earlier relation provided by Hogan \& Weston (1970), and especially with the one produced by $\mathbf{M}$. J. Ulyatt (unpublished results) for three grass and two clover diets consumed by grazing cattle and offered to stall-fed cattle, i.e.

$$
y=-0.01691 x+1.4304(\operatorname{RSD} 0.402, r 0.72) \text {, }
$$

where $y$ and $x$ are as defined previously, giving a value of $25.5 \mathrm{~g} / \mathrm{kg}$ OM of dietary $\mathrm{N}$ content at or below which NAN flow equals or exceeds $\mathrm{N}$ intake.

Similar effects have been observed earlier with fresh forages offered to stall-fed sheep by Beever et al. (1976, 1978b) and by MacRae \& Ulyatt (1974), and with sheep on fresh pasture 
by Corbett et al. (1982). In a recent review of fresh forage utilization, Beever \& Siddons (1986) suggested that the major cause of the effect was the readily soluble nature of the $\mathrm{N}$ constituents of fresh forage, which gave rise to a supply of degraded $\mathrm{N}$, and in particular $\mathrm{NH}_{3}$, in excess of the capacity of the rumen microbes to assimilate the available $\mathrm{N}$ into microbial biomass. Thus they found that whilst apparent efficiences of microbial $\mathrm{N}$ synthesis were generally high on fresh forages (Corbett et al. 1982; Cammell et al. 1983), efficiency of capture of degraded $\mathrm{N}$ by the microbes, even when the diets often contained significant levels of readily available water-soluble carbohydrate, was often poor. In a recent experiment with dairy cows fed on a 50:50 mixture of perennial ryegrass and white clover (D. E. Beever, D. J. Thomson and R. C. Siddons, unpublished results) an apparent net absorption, of $\mathrm{NH}_{3}$ from the pre-duodenal part of the alimentary tract of $147 \mathrm{~g} \mathrm{~N} / \mathrm{d}$ was observed and, along with an estimated absorption of $\mathrm{NH}_{3}$ post-duodenum of $58 \mathrm{~g} \mathrm{~N} / \mathrm{d}$, it was found that almost $30 \%$ of the ingested $\mathrm{N}(600+\mathrm{g} / \mathrm{d})$ was absorbed from the alimentary tract as $\mathrm{NH}_{3}$.

In further agreement with Beever \& Siddons (1986) and Beever et al. (1985), the results of the present study would suggest that on all the diets, rumen degradation of the ingested nutrients which were potentially digestible grossly outweighed an enhanced passage of undegraded dietary constituents from the rumen, as has been suggested may occur on some fresh forage diets, especially white clover (Moseley \& Jones, 1984). With all diets except $\mathrm{R} 1$, over $80 \%$ of the ingested cellulose was digested in the reticulo-rumen, and values on the clover diets tended to be higher than those found for the grass diets. Equally, estimates of the proportion of digestible OM apparently digested in the rumen indicated no significant difference with respect to forage species.

A similar effect with respect to site of OM digestion due to forage species was noted by Ulyatt et al. (1981), but the results of their study and the present one are in contrast to the reduced apparent digestion of OM in the rumen noted on white clover by Beever et al. (1985) when the same diets as those used by Ulyatt et al. (1981) were offered to housed cattle. In the present study, estimates of microbial OM synthesis were not made, so direct calculation of the proportion of the digestible OM consumed truly fermented in the rumen was not possible. However, on the basis of other studies (Cammell et al. 1983), assuming that microbial $\mathrm{N}$ represented 0.76 and 0.68 of duodenal NAN for ryegrass and white clover respectively, and microbial biomass contains $100 \mathrm{~g} \mathrm{~N} / \mathrm{kg}$ microbial $\mathrm{OM}$, it can be calculated that on all diets, in excess of $935 \mathrm{~g} \mathrm{OM}$ were truly digested in the reticulo-rumen per $\mathrm{kg}$ DOMI, with no obvious difference attributable to either forage species (mean values: grass 970 , clover $970 \mathrm{~g} / \mathrm{kg}$ ) or seasonal effects. Clearly, such findings give no indication of an enhanced passage of undigested but potentially digestible material of dietary origin from the rumen, and suggest that extensive rumen digestion occurred on all diets.

From the findings obtained in the present study it is apparent that both forage species and seasonal effects could, through variations in the amount of forage voluntarily consumed by the animal, the composition of that forage, and the subsequent digestion and utilization of the dietary components within the reticulo-rumen, have a significant effect on overall nutrient supply. In the present experiment, NAN availability in the small intestine or ME contents of the diets were not determined, but if respective values of 0.63 from MacRae \& Ulyatt (1974) and 15.83 MJ ME/kg DOMI from Ulyatt et al. (1981) and Cammell et al. (1986) are used, then likely quantities of absorbed NAN/MJ ME can be estimated.

Values varied between 1.04 and 1.68 g absorbed NAN/MJ ME, with the range noted on the grass diets $(1 \cdot 04-1 \cdot 68)$ being much greater than that on the clover diets $(1 \cdot 28-1 \cdot 62)$. Differences attributable to forage species were restricted to the mid-season, when between days 45 and 75 (approximately mid-June to mid-July) clover values were consistently higher than those found for the grass diets. Otherwise, overall seasonal effects were insignificant; 
average values over days $85-120$ for both forages were $1.47 \mathrm{~g} / \mathrm{MJ} \mathrm{ME}$ compared with an average value of $1.56 \mathrm{~g} / \mathrm{MJ} \mathrm{ME}$ obtained up to day 35 of the experiment.

In conclusion, this study has confirmed that both forage species and stage of growth or season can markedly influence the digestion of ingested nutrients and the overall supply and composition of the absorbed nutrients in grazing cattle. In the absence of relevant data on the partition of both the absorbed energy and protein fractions it is difficult to assess what impact the increased protein supply may have on animal performance. Studies with growing cattle receiving either zero-grazed ryegrass or white clover, at both equalized and ad lib. levels (Thomson et al. 1983), have illustrated marked improvements in both carcass protein deposition and carcass protein: fat value in animals fed on white clover, and it must be concluded that at least part of these differences could be attributed to the increased supply of NAN on clover diets as noted in this study. Furthermore, the findings of the present study and that of Thomson et al. (1983) allow interesting comparisons to be drawn with the studies of Barry et al. (1982) and Black et al. (1979), which have reported significant production and carcass compositional changes in lambs receiving $\mathrm{N}$ supplementation to fresh ryegrass pasture.

The authors wish to thank Mr A. R. Austin for care of the animals, Mr M. S. Dhanoa for statistical assistance, and Messrs R. J. Barnes, D. L. Gale, J. Paradine and R. C. Siddons for analytical assistance. The Animal and Grassland Research Institute is financed through the Agricultural and Food Research Council, and this work forms part of a commission by the Ministry of Agriculture, Fisheries and Food.

\section{REFERENCES}

Bailey, R. W. (1964). New Zealand Journal of Agricultural Research 7, 496-507.

Barry, T. N., Manley, S. R., Davis, S. R. \& Redekopp, C. (1982). In Forage Protein in Ruminant Animal Production, Occasional Publication of the British Society of Animal Production no. 6, pp. 146-148 [D. J. Thomson, D. E. Beever and R. G. Gunn, editors]. Thames Ditton: British Society of Animal Production.

Beever, D. E. (1980). In Forage Conservation in the 80's, pp. 131-143. [C. Thomas, editor]. Brighton: British Giassland Society.

Beever, D. E., Cammell, S. B. \& Wallace, A. S. (1974). Proceedings of the Nutrition Society 33, 73 A.

Beever, D. E., Kellaway, R. C., Thomson, D. J., MacRae, J. C., Evans, C. C. \& Wallace, A. S. (1978a). Journal of Agricultural Science, Cambridge 90, 157-163.

Beever, D. E. \& Siddons, R. C. (1986). Proceedings of VIth International Symposium on Ruminant Physiology, Banff, September 1984 (In the Press).

Beever, D. E., Terry, R. A., Cammell, S. B. \& Wallace, A. S. (1978b). Journal of Agricultural Science, Cambridge 90, 463-470.

Beever, D. E., Thomson, D. J. \& Cammell, S. B. (1976). Journal of Agricultural Science, Cambridge 88, 61-70.

Beever, D. E., Thomson, D. J., Pfeffer, E. \& Armstrong, D. G. (1971). British Journal of Nutrition 26, $123-134$.

Beever, D. E., Thomson, D. J., Ulyatt, M. J., Cammell, S. B. \& Spooner, M. C. (1985). British Journal of Nutrition 54, 763-775.

Black, J. L., Dawes, S. T., Colebrook, W. F. \& James, K. J. (1979). Proceedings of the Nutrition Society of Australia 4, 126

Cammell, S. B. (1977). Technical Report no. 24. Hurley: Grassland Research Institute.

Cammell, S. B., Beever, D. E., Thomson, D. J., Austin, A. R., Losada, H. R., Evans, R. T., Spooner, M. C. \& Terry, R. A. (1983). Animal Production 36, 501.

Cammell, S. B., Thomson, D. J., Beever, D. E., Haines, M. J., Dhanoa, M. S. \& Spooner, M. C. (1986). British Journal of Nutrition 55, 669-680.

Christian, K. R. \& Coup, M. R. (1954). New Zealand Journal of Science and Technology A 36, 328-330.

Conway, E. J. \& Byrne, A. (1933). Biochemical Journal 27, 491-496.

Corbett, J. L., Furnival, E. P., Inskip, M. W. \& Pickering, F. S. (1982). Forage Protein in Ruminant Animal Production. Occasional Publication of the British Saciety of Animal Production no. 6, pp. 141-143 [D. J. Thomson, D. E. Beever and R. G. Gunn, editors]. Thames Ditton: British Society of Animal Production. 
Corbett, J. L., Lynch, J. J., Nicol, G. R. \& Beeston, J. W. V. (1976). Laboratory Practice 25, 458-462.

Crampton, E. W. \& Maynard, R. A. (1938). Journal of Nutrition 15, 387-395.

Egan, A. R. \& Ulyatt, M. J. (1980). Journal of Agricultural Science, Cambridge 94, 47-56.

Evans, C. C., MacRae, J. C. \& Wilson, S. (1977). Journal of Agricultural Science, Cambridge 89, 17-22.

Evans, R. T., Hayes, D. G. \& Beever, D. E. (1981 a). Laboratory Practice 30, 591-593.

Evans, R. T., Skelton, K. V. \& Beever, D. E. (198! $b$ ). Laboratory Practice 30, 997-1000.

Faichney, G. J. (1975). Digestion and Metabolism in the Ruminant, pp. 217-224 [I. W. McDonald and A. C. I. Warner, editors]. Armidale, Australia: University of New England Publishing Unit.

Green, J. O. \& Baker, R. D. (1981). Grassland in the British Economy, paper no. 10 pp. 237-247 [J. L. Jollans, editor]. Reading: Centre for Agricultural Strategy.

Hogan, J. P. \& Weston, R. H. (1970). Physiology of Digestion and Metabolism in the Ruminant, pp. $474-485$ [A. T. Phillipson, editor]. Newcastle upon Tyne: Oriel Press.

Losada, H. R., Cammell, S. B., Beever, D. E., Evans, R. T. \& Haines, M. J. (1982). In Forage Protein in Ruminant Animal Production, Occasional Publication of the British Society of Animal Production no. 6, pp. 144-145 [D. J. Thomson, D. E. Beever and R. G. Gunn, editors]. Thames Ditton: British Society of Animal Production.

MacRae, J. C. \& Ulyatt, M. J. (1974). New Zealand Journal of Agricultural Research 82, 309-312.

Moseley, G. \& Jones, J. R. (1984). British Journal of Nutrition 52, 381-390.

Tan, N. H., Hogan, J. P. \& Weston, R. H. (1971). International Journal of Applied Radiation \& Isotopes 22, 301-308.

Thomson, D. J., Haines, M. J., Austin, A. R., Cammell, S. B., Beever, D. E., Dhanoa, M. S. \& Barnes, R. L. (1983). Animal Production 36, 501.

Tilley, J. M. A. \& Terry, R. A. (1963). Journal of the British Grassland Society 18, 104-111.

Ulyatt, M. J., Beever, D. E., Thomson, D. J., Evans, R. T.\& Haines, M. J. (1981). Proceedings of Nutrition Society 39, $67 \mathrm{~A}$.

Ulyatt, M. J. \& Egan, A. R. (1979). Journal of Agricultural Science, Cambridge 92, 605-616.

Ulyatt, M. J. \& MacRae, J. C. (1974). Journal of Agricultural Science, Cambridge 82, 295-307.

Van Soest, P. J. \& Wine, R. H. (1967). Journal of the Association of Official Analytical Chemists 50, 50-55. 